\title{
Qualitative and quantitative tear film abnormalities in dogs
}

\author{
Anormalidades quali-quantitativas do filme lacrimal de cães
}

\author{
Alexandre Pinto Ribeiro ${ }^{\mathrm{I}}$ Fabio Luiz da Cunha Brito ${ }^{\mathrm{II}}$ Bianca da Costa Martins ${ }^{\mathrm{I}}$ \\ Fabrício Mamede ${ }^{\mathrm{I}}$ José Luiz Laus ${ }^{\mathrm{III}}$
}

- REVISÃO BIBLOGRÁFICA -

\begin{abstract}
Tear film disorders in dogs can be classified into quantitative or qualitative abnormalities, or both, and are commonly observed in daily clinical practice. Inadequate production of one or more tear film components can lead to variable degrees of ocular disorders, called keratoconjunctivitis sicca. Keratoconjunctivitis sicca in dogs has several causes, but in most cases the disease is idiopathic, with $T$ lymphocytes playing a role. In veterinary medicine, the diagnosis is made based on the results of the Schirmer tear test. In this article, we review aspects related to the etiopathogenesis and diagnosis of keratoconjunctivitis sicca in dogs and discuss new therapeutic modalities for this disease.
\end{abstract}

Key words: dogs, tear film, keratoconjunctivitis sicca, lacrimomimetics, lacrimostimulants, immunosuppressors.

\section{RESUMO}

Anormalidades do filme lacrimal de cães podem ser classificadas quanto ao seu aspecto quantitativo, qualitativo ou ambos, sendo comumente observada na prática cotidiana. Intercorrências na produção de um ou mais componentes do filme lacrimal ensejam distúrbios oculares em graus variados, denominados ceratoconjuntivite seca. Diversas são as causas da ceratoconjuntivite seca em cães, mas a maioria dos casos é de caráter idiopático, estando associada à participação de linfócitos $T$. $O$ diagnóstico em medicina veterinária é firmado com base nos valores obtidos pelo teste da lacrimal de Schirmer.
O presente artigo objetiva revisar os aspectos relacionados à etiopatogenia e ao diagnóstico da ceratoconjuntivite seca em cães, assim como discutir novas modalidades terapêuticas para a doença.

Palavras-chave: cães, filme lacrimal, ceratoconjuntivite seca, lacrimomiméticos, lacrimoestimulantes, imunossupressores.

\section{INTRODUCTION}

Keratoconjunctivitis sicca (KCS), also called "dry eye", is a chronic inflammatory disease notably characterized by the deficient production of the aqueous portion of the tear film (quantitative disorder) (GRAHN \& STOREY, 2004). Excessive tear evaporation (qualitative disorder) is the result of inadequate production of the lipid layer. Quantitative and qualitative tear film disorders are characterized by damage to the corneal and conjunctival surface, causing symptoms of ocular discomfort that vary in severity (GRAHN \& STOREY, 2004).

Dry eye is a common disorder in dogs, with its incidence ranging from 11 to 14.7\% (ANDRADE \& LAUS, 1997). Ocular complications in KCS are

${ }^{\mathrm{I} C u r s o ~ d e ~ P o ́ s-g r a d u a c ̧ a ̃ o ~ e m ~ C i r u r g i a ~ V e t e r i n a ́ r i a, ~ F a c u l d a d e ~ d e ~ C i e ̂ n c i a s ~ A g r a ́ r i a s ~ e ~ V e t e r i n a ́ r i a s ~(F C A V), ~ U n i v e r s i d a d e ~ E s t a d u a l ~}$ Paulista (UNESP), Jaboticabal, SP, Brasil.

"Departamento de Medicina Veterinária, Universidade Federal Rural de Pernambuco, Unidade Acadêmica de Garanhuns, Recife, PE, Brasil.

"IIDepartamento de Clínica e Cirurgia Veterinária, FCAV/UNESP. Via de acesso Professor Paulo Donato Castellane, 14870-000, Jaboticabal, SP, Brasil. E-mail: jllaus@fcav.unesp.br. Autor para correspondência. 
characterized by events affecting the ocular surface. Progressive corneal disease (vascularization, pigmentation and corneal edema), accompanied or not by loss of the corneal epithelium, ocular pain and reduced vision are common conditions (GRAHN \& STOREY, 2004). Corneal-conjunctival inflammation in dogs with dry eye is mainly characterized by T-cell infiltration (SMITH, 2005). The disease is more common in older animals and the most frequently affected breeds are Cocker Spaniels, West Highland White Terriers and brachycephalic breeds in general, with the disease being more frequent in females than in males (BARROS et al., 1992).

In this article, we review aspects related to the etiopathogenesis and diagnosis of keratoconjunctivitis sicca in dogs and discuss new therapeutic modalities.

Anatomophysiology of the lacrimal system

The lacrimal system consists of a secretory and an excretory component which are responsible for the production and excretion of the tear film, respectively (CABRAL et al., 2005). The secretory portion comprises the orbital lacrimal and third eyelid glands, in addition to conjunctival goblet cells (CABRAL et al., 2005). The lacrimal glands are histologically characterized as tubuloacinar structures consisting of secretory units, ducts and supporting connective tissue. The epithelial components (ducts and secretory units) form the glandular parenchyma. Connective tissue, blood vessels and nerve fibers comprise the glandular stroma. Male lacrimal glands are larger than female ones (CABRAL et al., 2005). The orbital lacrimal and third eyelid glands are innervated by sympathetic and parasympathetic nerve fibers and primary control is mainly exerted by the parasympathetic nervous system (GRAHN \& STOREY, 2004).

The preocular tear film is a complex trilaminar fluid measuring approximately 7 to $10 \mu \mathrm{m}$. The outermost layer consists of lipids produced by the tarsal glands (meibomian glands) which form a thin oily cover $(0.05-0.1 \mu \mathrm{m})$ on the aqueous tear layer, thus reducing the effects of evaporation. The intermediate or aqueous layer is secreted by the orbital lacrimal $(60 \%)$ and third eyelid glands (40\%) and is the largest layer of the tear film, measuring approximately $7 \mu \mathrm{m}$. In addition to water, this layer contains electrolytes, glucose, urea, active surface polymers, glycoproteins and lacrimal proteins, including immunoglobulin A, albumin, beta-lysine, lysozyme and lactoferrin, with the three last components having antimicrobial properties (GRAHN \& STOREY, 2004). The deepest layer measures approximately $1.0 \mu \mathrm{m}$ and consists of mucin. Mucin is a hydrated glycoprotein produced by goblet cells of the conjunctival fornix. The main function of this layer is to correct corneal surface irregularities, in addition to promoting tear adhesion to the corneal epithelium (GRAHN \& STOREY, 2004).

The tear film is responsible for lubrication of the ocular surface and eyelids, and for nutrition of the cornea, assists in the distribution of leukocytes, and cleaning of the ocular surface. The excretory portion comprises the drainage system which starts in the lacrimal puncta, followed by the lacrimal canaliculi; lacrimal sac and nasolacrimal duct (GRAHN \& STOREY, 2004).

\section{Etiopathogenesis}

Studies support the view that most cases of $\mathrm{KCS}$ in dogs are the result of immunomediated disorders since affected animals frequently exhibit Tcell infiltration in the lacrimal glands and respond to immunosuppressive therapy with cyclosporin A (GAO et al., 1998; SMITH, 2005). There is circumstantial evidence that the disease resembles Sjögren's syndrome in humans (SNYDER, 2003; SMITH, 2005). Sjögren's syndrome is a systemic autoimmune disease characterized by KCS, xerostomia (dry mouth) and plasmacytic lymphadenitis as also described in dogs (SNYDER, 2003).

A new concept for the pathogenesis of $\mathrm{KCS}$ in humans has been postulated. According to this proposal, epithelial cells of the conjunctiva regularly secrete antigens or cellular proteins. In normal states, these antigens are recognized by antigen-presenting cells and then presented to effector lymphocytes on the ocular surface. In parallel, regulatory lymphocytes which are also present block the action of effector lymphocytes, thus preventing the development of an inflammatory state and maintaining local immunohomeostasis (SMITH, 2005). This pathway is believed to be regulated by androgens which are responsible for the regulation of the production of transforming growth factor $\beta$ (TGF- $\beta$ ) whose function is to reduce local prolactin concentration. Conditions such as senility and idiopathic factors may reduce the production of androgen hormones, leading to changes in conjunctival immunohomeostasis due to the reduced production of TGF- $\beta$ and increased prolactin concentration in conjunctival epithelial cells. This in turn would alter local antigen detection, favoring the effector lymphocyte pathway and thus triggering local inflammation (SMITH, 2005) (Figure 1).

Other causes of KCS include immunomediated dacryoadenitis, distemper virus 
infection (due to inflammation generated by direct action of virus in the conjunctival cells), congenital acinar hypoplasia, chronic blepharoconjunctivitis (due to entropion, ectropion, trichiasis and atopy), protrusion of the third eyelid gland, traumatic proptosis (GRAHN \& STOREY, 2004). NARANJO et al. (2005) recently reported that dogs affected with leishmaniasis develop KCS by direct parasitism of the agent in the ductal component of the lachrymal glands and also in the Meibonian glands, by means of immunohistochemistry.

Some drugs also have the potential to induce KCS which, in many cases, might become irreversible as reported for the use of sulfonamides (TREPANIER et al., 2003). The mechanism of action of sulfonamides in KCS is not completely understood, but it is believed to be a response of $\mathrm{T}$ cells to haptens generated by oxidative metabolites derived from these substances (TREPANIER, 2004). Topical application of $1 \%$ atropine (MARGADANT et al., 2003) and administration of the anti-inflammatory drug etodolac (STILES, 2004) have been shown to reduce tear production. In cases of uveítes associated with KCS tropicamide cold be a choice (MARGADANT et al., 2003). Procedures performed under general anesthesia lasting longer than two hours can lead to a significant decrease in tear production(HERRING et al., 2000).
Removal of the third eyelid gland results in qualitative (SAITO et al., 2001) and quantitative abnormalities (ALMEIDA et al., 2004) in tear production. Likewise, damage to the facial nerve (cranial nerve VII) accidentally produced by surgical ablation of the auditory canal was found to be associated with iatrogenic KCS (LANZ \& WOOD, 2004). Recently, cyclophotocoagulation of the ciliary body with a laser for the treatment of glaucoma in dogs has been recognized as a potential cause of KCS, favoring the installation of corneal ulcers (WEIGT et al., 2002).

Metabolic diseases such as hypothyroidism, hyperadrenocorticism and diabetes mellitus have been associated with KCS (BARRERA et al., 1992; KAISERMAN et al., 2005). A decrease of corneal sensitivity has been demonstrated in diabetic humans (ROSENBERG et al., 2000) and dogs (GOOD et al., 2003). Corneal hypoesthesia may reduce tear production (GOOD et al., 2003). Other mechanisms cited involve possible damage to the microvasculature of the lacrimal gland (KAISERMAN et al., 2005). Some studies have reported that dry eye in diabetic humans and dogs is reversed by stabilizing glycemia (BARRERA et al., 1992; KAISERMAN et al., 2005).

KCS may occur in dogs even when tear production is within normal reference values (GRAHN \& STOREY, 2004). Deficient mucin production is normally an acquired condition secondary to chronic

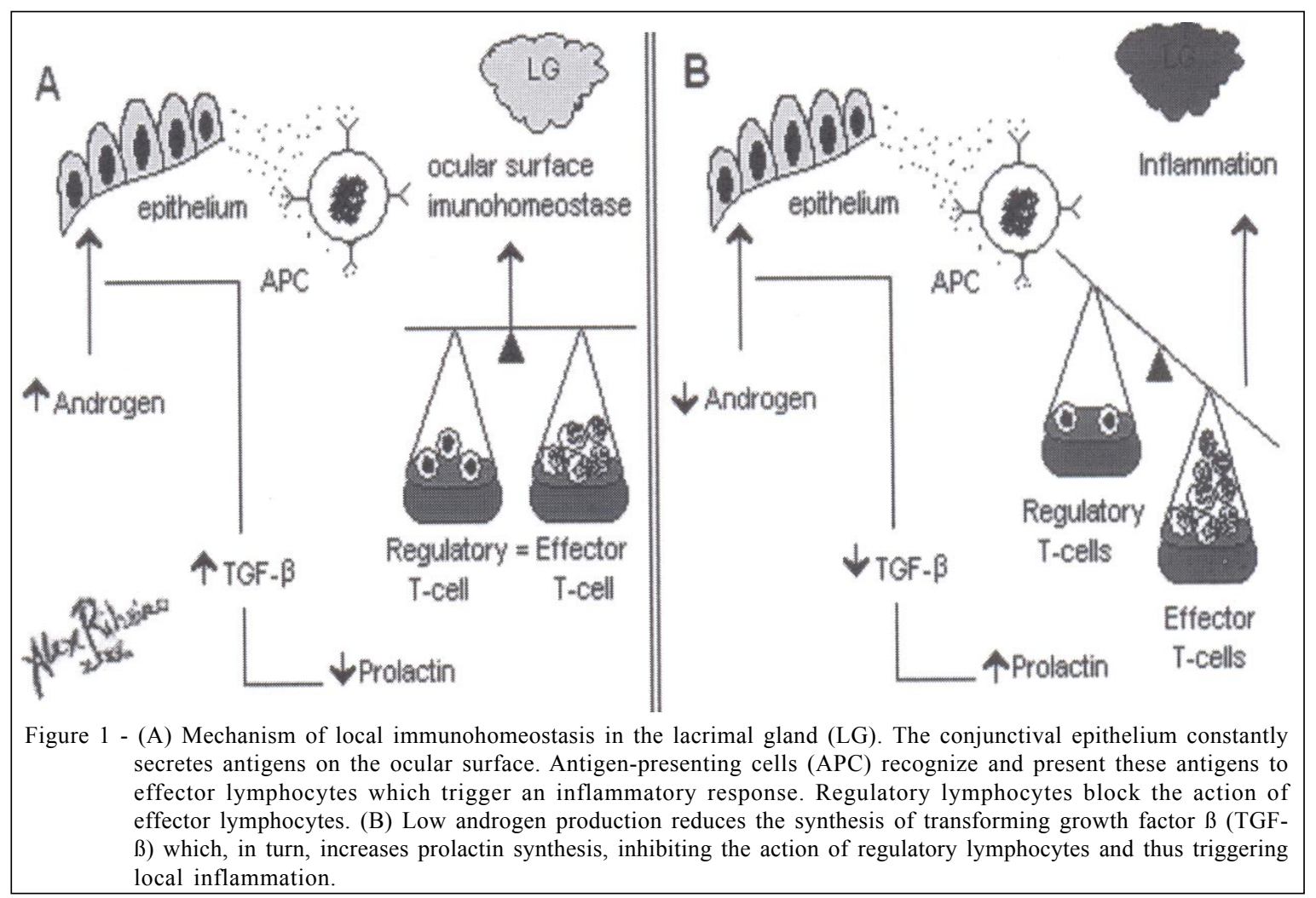

Ciência Rural, v.38, n.2, mar-abr, 2008. 
blepharoconjunctivitis (GRAHN \& STOREY, 2004). Decreased lipid layer production is observed in older dogs and is due to abnormal secretion of the tarsal glands affected by chalazion, a condition common in elderly animals (GRAHN \& STOREY, 2004).

\section{Clinical signs}

Qualitative and quantitative tear film abnormalities can show similar clinical signs, including conjunctival hyperemia, blepharospasm, and variable degrees of keratitis with or without corneal ulcer (GRAHN \& STOREY, 2004). Ophthalmorrhea leads to a suspicion of bacterial conjunctivitis. However, its occurrence is normally secondary to KCS in these cases (ANDRADE \& LAUS, 1997).

\section{Diagnosis}

Tear production abnormalities are commonly diagnosed using the Schirmer tear test (STT). Two types of the STT have been described (SST-1 and SST2) (SAITO \& KOTANI, 2001, GRAHN \& STOREY, 2004; BARABINO et al., 2004). The STT-1 measures basal and reflex tear production and is the most commonly used test (SAITO \& KOTANI, 2001, GRAHN \& STOREY, 2004; BARABINO et al., 2004). The STT-2 evaluates basal tear production after topical application of an anesthetic and is of predictive values in animals with corneal ulceration which do not tolerate the STT1 (SAITO \& KOTANI, 2001).

The STT is performed by inserting a special paper strip into the conjunctival fornix for one minute and the results are reported as $\mathrm{mm} \mathrm{min}^{-1}$ (GRAHN \& STOREY, 2004, BARABINO et al., 2004). For most dog breeds, values of approximately $20 \mathrm{~mm} \mathrm{~min}^{-1}$ in the STT1 and 4 to $5 \mathrm{~mm} \mathrm{~min}^{-1}$ in the STT-2 are considered to be normal (SAITO \& KOTANI, 2001; BARABINO et al., 2004). Special attention should be paid when evaluating tear production in Shetland Sheepdogs since this breed in particular presents low values in the STT-1 (15.8 \pm $\left.1.8 \mathrm{~mm} \mathrm{~min}^{-1}\right)$ and STT-2 $\left(3.6 \pm 2.8 \mathrm{~mm} \mathrm{~min}^{-1}\right)($ HAMOUR et al., 2000). In neonates with a mean age of 22 to 28 days, STT-1 and STT-2 values are approximately 13.63 \pm 3.45 and $3.68 \pm 1.75 \mathrm{~mm} \mathrm{~min}^{-1}$, respectively (Da SILVA \& GALERA, 2004). Values obtained with commercial STT strips cannot be extrapolated to modified strips since differences in the absorptive capacity between these strips have been reported (van der WOERDT \& ADACAK, 2000).

Study reported that in dogs STT decreases, annually, $0.4 \mathrm{~mm} \mathrm{~min}^{-1}$. In addition, values taken during the morning are $0.7 \mathrm{~mm}$ lower than values taken at afternoon (HARTLEY et al., 2006).

STT-1 values of 10 to $15 \mathrm{~mm} \mathrm{~min}^{-1}$ indicate a suspicion of $\mathrm{KCS}$, and animals presenting values of less than $10 \mathrm{~mm} \mathrm{~min}^{-1}$ can be considered to have KCS (GRAHN \& STOREY, 2004).

An alternative method for the estimation of tear production in dogs is the phenol-red thread test. The principle of this technique is similar to that of the STT but the test lasts only 15 seconds (SAITO \& KOTANI, 2001; GRAHN \& STOREY, 2004). The examiner should use the millimeter scale printed on the box of the strips (BARABINO et al., 2004). Reference values for dogs ranges from 30 to $38 \mathrm{~mm} / 15$ seconds (SAITO \& KOTANI, 2001; GRAHN \& STOREY, 2004).

Qualitative tear film abnormalities can be diagnosed by measuring the tear film breakup time (BARABINO et al., 2004). Animals with qualitative disorders can show normal STT values (GRAHN \& STOREY, 2004). The tear film breakup time is evaluated by biomicroscopy using a cobalt blue filter after topical instillation of fluorescein. The normal time of tear film breakup in dogs is approximately 20 seconds or more (SAITO \& KOTANI, 2001). Values of less than 20 seconds are considered to indicate KCS when associated with ophthalmological signs of the disease (BARABINO et al., 2004).

\section{Medical management}

Topical drug treatment is the most appropriate approach to the control of KCS and should be adapted for each patient (GRAHN \& STOREY, 2004). Treatment basically consists of the application of lacrimomimetics, anti-inflammatory agents (except in the presence of ulcerative keratitis), and mainly lacrimostimulants such as cyclosporin A (ANDRADE \& LAUS, 1997; GRAHN \& STOREY, 2004).

\section{Lacrimomimetics}

Lacrimomimetics are agents containing moisturizing substances aimed at replacing one or more deficient components of the tear film. The appropriate lacrimomimetic should be selected based on the nature of the deficiency and should be used as adjuvant therapy to lacrimostimulants until the latter restore normal tear production. Lacrimomimetics are available in different formulations containing hypromellose, dextran, carboxymethylcellulose, chondroitin sulfate, and polyacrylic acid. To be effective, they should be prescribed six times per day, and if adverse reactions are referred, change to free preservatives lacrimomimetics are recommended. Once the reference values are reestablished, the use of lacrimomimetics can be discontinued (GRAHN \& STOREY, 2004).

\section{Lacrimostimulants}

Lacrimostimulants are drugs able to stimulate tear production and include 
immunosuppressive/anti-inflammatory agents (cyclosporin A, pimecrolimus, tacrolimus and sirolimus), cholinergic drugs (pilocarpine), agents such as diquafosol tetrasodium and nerve growth factor, and drugs with immunomodulatory properties (interferons).

\section{Cyclosporin A}

Cyclosporin A is a polypeptide produced by two fungal species (Tolypocladium inflatum and Cylindrocarpon lucidum). Cyclosporin acts on a CD3 receptor on the surface of lymphocytes, increasing intracellular calcium concentration which stimulates phosphatase activity by calcineurin. Calcineurin, in turn, binds to a specific immunophilin (cyclophilin), inhibiting the production of interleukin-2 and interferons by T cells (MOORE, 2004). Cyclosporin A is the only immunosuppressive drug approved for the treatment of KCS in humans (SMITH, 2005) and animals (GRAHN\& STOREY, 2004).

Cyclosporin is normally administered topically at a concentration of $0.2 \%$ and can be formulated at increasing concentrations of up to $2 \%$ in corn, olive or almond oil (IZCI et al., 2002; GRAHN \& STOREY, 2004), or as $1 \%$ ointment (ALMEIDA et al., 2004). The drug is initially administered at 12-hour intervals, but can be reduced to one daily application if the STT values reach a minimum of $20 \mathrm{~mm} \mathrm{~min}^{-1}$ (GRAHN \& STOREY, 2004). Cyclosporin is a highly lipophilic drug of unknown half-life when administered topically, reaching high concentrations in the cornea, sclera and lacrimal glands (MOORE, 2004). Studies conducted on dogs with KCS have shown that topical administration of $2 \%$ cyclosporin suppresses peripheral (GAO et al., 1998) and systemic (IZCI et al., 2002) lymphocyte proliferation. The reduction in the number of lymphocytes is due to the induction of apoptosis in these cells, with a consequent suppression of conjunctival and lacrimal epithelial cell apoptosis (GAO et al., 1998).

Topical use of $0.2 \%$ cyclosporin is safe and does not favor the occurrence of ocular infections (GRAHN \& STOREY, 2004). However, patients under topical treatment with high concentrations should be monitored because of the systemic decline in CD4+ and CD8+ lymphocyte populations (IZCI et al., 2002). Cyclosporin treatment should not be interrupted since discontinuation may lead to the recurrence of clinical signs (ANDRADE \& LAUS, 1997; IZCI et al., 2002).

A subconjunctival slow-release device for cyclosporin has been recently tested in healthy dogs. Although the animals tolerated the device (BEALE et al., 2004), further studies are necessary to determine its true efficacy in dogs (BEALE et al., 2004).
Pimecrolimus

Pimecrolimus is an ascomycin derivative which selectively interferes with the activation of $\mathrm{T}$ cells and mast cells, inhibiting the production of inflammatory cytokines. At the molecular level, pimecrolimus binds to the macrophilin-12 receptor, inhibiting calcineurin, with a consequent blockade of the production of interleukin-2 and of type 1 and 2 helper T cells (NELL et al., 2005).

In veterinary ophthalmology, a recent study has demonstrated that topical application (one drop, three times a day) of a $1 \%$ solution prepared in corn oil was able to significantly increase STT values in dogs with KCS and to reduce corneal inflammation in dogs with superficial keratitis (NELL et al., 2005). In another study, $1 \%$ pimecrolimus was found to be effective in the control of corneal inflammation and in the stimulation of tear production compared to a commercial cyclosporin formulation (OFRI et al., 2004). The superiority of pimecrolimus might be attributed to its low molecular weight (811 daltons), a fact favoring its tissue penetration compared to cyclosporin which has a higher molecular weight (1202 daltons) (NELL et al., 2005).

\section{Tacrolimus}

Tacrolimus is a macrolide antibiotic isolated from Streptomyces tsucrenaenseis, which is 10 to 100 times more potent in vitro than cyclosporin A. Tacrolimus binds to a specific immunophilin, FK506, and its mechanism of action resembles that of cyclosporin (MOORE, 2004). However, administered systemically tacrolimus can trigger more severe side effects than cyclosporin, including nephrotoxicity (MOORE, 2004).

A topical aqueous solution of $0.02 \%$ tacrolimus was found to be effective in increasing tear production in dogs with KCS. A $0.02 \%$ olive oil-based solution was safe when applied topically to healthy dogs (GRAHN \& STOREY, 2004).

Interferons

Interferons are cytokines with useful properties in ophthalmology due to their antiviral action. Viral infections stimulate the secretion of interferons into the extracellular spaces of affected cells, which then bind to specific receptors on neighboring cells, inhibiting the transcription of viral proteins and protecting other cells (MOORE, 2004).

GILGER et al. (1999) observed that oral administration of 20 to $40 \mathrm{IU}$ of interferon- $\alpha$ significantly increased tear production in dogs with KCS after 12 
weeks of treatment, notably in animals presenting previous STT values of $6 \mathrm{~mm} \mathrm{~min}^{-1}$ or higher.

Diquafosol tetrasodium

Diquafosol tetrasodium is a new dinucleotide which functions as an agonist at the P2Y2 receptor and has been developed for the treatment of dry eye in humans. The drug promotes nonglandular secretion of fluid probably by water transport via activation of chloride channels, as well as the secretion of mucin and possibly the production of lipids by meibomian glands (TAUBER et al., 2004).

Diquafosol tetrasodium has been shown to facilitate healing of the ocular surface after chronic inflammation in cases of experimentally induced KCS in rats (TAUBER et al., 2004). A study conducted on 527 human patients demonstrated that $1 \%$ and $2 \%$ concentrations of the drug relieved symptoms of ocular discomfort in the dry eye, in addition to significantly increasing tear production by the second week of treatment. In that study, diquafosol was found to be safe and rapidly metabolized on the ocular surface into endogenous components such as uridine mono-, diand triphosphate (TAUBER et al., 2004).

\section{Nerve growth factor}

Nerve growth factor is an essential polypeptide since it regulates the growth and survival of developing neurons in the peripheral and central nervous system, in addition to restores the function of damaged neurons. Studies conducted on normal dogs have demonstrated the presence of nerve growth factor and its receptor TrKA in the lacrimal glands, cornea and tear film (BENTLEY \& MURPHY, 2004).

Recently, topical administration of $100 \mu 1$ of nerve growth factor twice daily was shown to significantly increase STT values, corneal sensitivity and mucin production, and to reduce inflammatory corneal haze in three dogs with iatrogenic $\mathrm{KCS}$ (COASSIN et al., 2005).

\section{Pilocarpine}

Pilocarpine is a nonspecific parasympathomimetic agent (GRAHN \& STOREY, 2004). Although some investigators have reported no beneficial effects of topical pilocarpine on the stimulation of tear production, veterinary ophthalmologists have been administering the drug at $1 \%$ or $2 \%$, topically or systemically ( $1 \mathrm{drop} 10 \mathrm{~kg}^{-1}$, orally) as an adjuvant to the treatment of neurogenic KCS in dogs unresponsive to cyclosporin (GRAHN \& STOREY, 2004).

Systemic administration of pilocarpine can cause side effects due to parasympathetic intoxication such as sialorrhea, vomiting, diarrhea and bradycardia (GRAHN \& STOREY, 2004). Topically, the drug causes adverse effects such as severe uveal inflammation, myosis and conjunctival hyperemia (KROHNE et al., 1998), which can be reversed by the topical administration of steroidal and nonsteroidal antiinflammatory drugs (KROHNE et al., 1998). Dilution of pilocarpine to a concentration of $0.25 \%$ in artificial tears minimizes the occurrence of inflammatory reactions (GRAHN \& STOREY, 2004)

Surgical management of kcs

Patients unresponsive to traditional therapy with cyclosporin A or other topical drugs for at least 8 weeks might benefit from transposition of the parotid salivary gland duct (GELATT \& GELATT, 2001). However, the procedure can lead to side effects such as the formation of calcium granules retained in the tarsal plate, in addition to mucocele and sialolithiasis, which may obstruct the transplanted duct (TERMOTE, 2003).

\section{FINAL CONSIDERATIONS}

Qualitative and quantitative tear film abnormalities are disorders commonly observed in daily clinical practice and may impair the vision of dogs or even cause blindness. Therefore, the STT is indispensable for any dog with ocular discharge.

The use of drugs such as sulfonamides, the anti-inflammatory etodolac and topical atropine should be discouraged in patients with KCS. In cases where uveits are in parallel to KCS, tropicamide could be used, once this agent does not alter the tear production.

Most patients with dry eye benefit from topical treatment with $0.2 \%$ cyclosporin A, especially when the STT values are higher than $2 \mathrm{~mm} \mathrm{~min}^{-1}$. New immunosuppressive drugs such as pimecrolimus and tacrolimus are valuable alternatives in patients who do not respond to topical cyclosporin A or present undesired effects originating from oral pilocarpine treatment. Among these substances, pimecrolimus is superior to cyclosporin and tacrolimus because of its greater tissue penetration due to its lower molecular weight.

Diquafosol tetrasodium is a promising alternative but no studies are available regarding the existence of P2Y2 receptors on the ocular surface of dogs. Nerve growth factor has been considered for the treatment of iatrogenic KCS in dogs. However, studies involving larger populations that compare its efficacy with that of cyclosporin, including cases of KCS of different etiologies, are sparce. It should be noted that, 
except for cyclosporin and pilocarpine, the substances discussed here are still in the experimental phase, with these agents not being currently available and their cost-benefit relationship being unknown.

The theory proposed by SMITH (2005) that surface antigens are constantly suppressed by effector lymphocytes may explain the effect of interferon on tear production. However, the link between androgen hormones and $\mathrm{T}$ lymphocytes during the pathogenesis of KCS in dogs is still unknown. Animals showing a low response to lacrimostimulants and a high anesthetic risk may benefit from occlusion of the lower lacrimal punctum.

\section{REFERENCES}

ALMEIDA, D.E. et al. Iatrogenic keratoconjunctivitis sicca in a dog. Ciência Rural, v.34, n.3, p.921-924, 2004.

ANDRADE, A.L.; LAUS. J.L. Enfermidades da córnea de pequenos animais. Clínica Veterinária, n.12, p.34-39, 1997.

BARABINO, S. et al. Tear film and ocular surface tests in animal models of dry eye: uses and limitations. Experimental Eye Research, v.79, p.613-621, 2004.

BARRERA, R. et al. Keratoconjunctivitis sicca and diabetes mellitus in a dog. Journal of the American Veterinary Medical Association, v.200, n.12, p.1967-1968, 1992.

BARROS, P.S.M. et al. Aspectos clínicos da ceratoconjuntivite seca em cães. Estudo retrospectivo em 223 casos. ARS Veterinária, v.8, n.1, p.6-14, 1992.

BEALE, A.B. et al. Ocular toxicity of subconjunctival sustained release cyclosporine delivery devices in dogs [abstract]. In: (ANNUAL MEETING OF THE AMERICAN COLLEGE OF VETERINARIAN OPHTHALMOLOGISTS), 2004, Washington, DC, USA. Veterinary Ophthalmology, v.7, n.6, p.437-453, 2004.

BENTLEY, E.; MURPHY, C.J. Topical therapeutic agents that modulate corneal wound healing. Veterinary Clinics of North America: Small Animal Practice, v.34, n.3, p.623$638,2004$.

CABRAL, P.V. et al. Canine lacrimal and third eyelid superficial glands macroscopic and morphometric characteristics. Ciência Rural, v.35, n.2, p.391-397, 2005.

COASSIN, M. et al. Efficacy of topical nerve growth factor treatment in dogs affected by dry eye. Graefes Archives of Clinical and Experimental Ophthalmology, v.243, n.2, p. $151-155,2005$.

Da SILVA, E.G.; GALERA, P.D. Evaluation of tear formation during neonatal period in small breed dogs, using the Schirmer tear test: STT1 \& STT2 [abstract]. In: (ANNUAL MEETING OF THE AMERICAN COLLEGE OF VETERINARIAN OPHTHALMOLOGISTS), 2004, Washington, DC, USA. Veterinary Ophthalmology, v.7, n.6, p.437-453, 2004.
GAO, J. et al. The role of apoptosis in the pathogenesis of canine keratoconjunctivitis sicca: the effect of topical cyclosporine A therapy. Cornea, v.17, n.6, p.654-663, 1998.

GELATT, K.N.; GELATT, J.P. Surgery of nasolacrimal apparatus and tear systems. In:_____ Small animal ophthalmic surgery: practical techniques for the veterinarian. Oxford: Butterworth \& Heinemann, 2001. p. 125-141.

GILGER, BC. et al. Low-dose oral administration of interferonalpha for the treatment of immune-mediated keratoconjunctivitis sicca in dogs. Journal of Interferon and Cytokine Research, v.19, n.8, p.901-905, 1999.

GOOD, K. et al. Corneal sensitivity in dogs with diabetes mellitus. American Journal of Veterinary Research, v.64, n.1, p.7-11, 2003.

GRAHN, B.H.; STOREY, E.S. Lacrimomimetics and lacrimostimulants. Veterinary Clinics of North America: Small Animal Practice, v.34, n.3, p.739-753, 2004.

HAMOUR, R.E. et al. Evaluation of results for Schirmer tear test conduced with and without application of a topical anesthetic in clinically normal dogs of 5 breeds. American Journal of Veterinary Research, v.61, n.11, p.1422-1425, 2000.

HARTLEY, C. et al. Effect of age, gender, weight, and time of day on tear production in normal dogs. Veterinary Ophthalmology, v.9, n.1, p.53-57, 2006.

HERRING, I.P. et al. Evaluation of aqueous tear production in dogs following general anesthesia. Journal of the American and Animal Hospital Association, v.36, n.5, p.427-430, 2000.

IZCI, C. et al. Histologic characteristics and local cellular immunity of the gland of the third eyelid after topical ophthalmic administration of $2 \%$ cyclosporine for treatment of dogs with keratoconjunctivitis sicca. American Journal of Veterinary Research, v.63, n.5, p.688-694, 2002.

KAISERMAN, I. et al. Dry eye in diabetic patients. American Journal of Ophthalmology, v.139, n.3, p.498-503, 2005.

KROHNE, S.G. et al. Inhibition of pilocarpine-induced aqueous humor flare, hypotony, and miosis by topical administration of anti-inflammatory and anesthetic drugs. American Journal of Veterinary Research, v.59, n.4, p.482-488, 1998.

LANZ, O.I.; WOOD, B.C. Surgery of the ear and pinna. Veterinary Clinics of North America: Small Animal Practice, v.34, n.2. p.567-599, 2004

MARGADANT, D.L. et al. Effect of topical tropicamide on tear production as measured by Schirmer's tear test in normal dogs and cats. Veterinary Ophthalmology, v.6, n.4, p.315$320,2003$.

MOORE, C.P. Immunomodulating agents. Veterinary Clinics of North America: Small Animal Practice, v.34, n.3, p.725737, 2004.

NARANJO, C. et al. Characterization of lacrimal gland lesions and possible pathogenic mechanisms of keratoconjunctivitis 
sicca in dogs with leishmaniasis. Veterinary Parasitology, v. 133 , n.1, p. 37-47, 2005.

NELL, B. et al. The effect of pimecrolimus on keratoconjunctivitis sicca and chronic superficial keratitis in dogs: results from an exploratory study. Veterinary Ophthalmology, v.8, n.1, p.39-46, 2005.

OFRI, R. et al. Successful treatment of keratoconjunctivitis sicca in dogs with pimecrolimus drops: a comparison with cyclosporine A ointment [abstract]. In: (ANNUAL MEETING OF THE AMERICAN COLLEGE OF VETERINARIAN OPHTHALMOLOGISTS), 2004, Washington, DC, USA. Veterinary Ophthalmology, v.7, n.6, p.437-453, 2004.

ROSENBERG, M.E. et al. Corneal structure and sensitivity in the type I diabetes mellitus. Investigative Ophthalmology and Visual Science, v.41, n.10, p.2915-2921, 2000.

SAITO, A. et al. The effect of eyelid removal on the ocular surface of dogs. Veterinary Ophthalmology, v.4, n.1, p.1318,2001

SAITO, A.; KOTANI, T. Estimation of lacrimal level and testing methods on normal beagles. Veterinary Ophthalmology, v.4, n.1, p.7-11, 2001

SNYDER, P.W. Síndrome de Sjögren. In: TILLEY, L.P.; SMITH, F.W.K. Consulta veterinária em 5 minutos. São Paulo: Manole, 2003. p.1198-1199.

SMITH, R.E. Tear film complex: pathogenesis and emerging therapies. Cornea, v.24,n.1, p.1-7, 2005.
STILES, J. Warning of an adverse affect of etodolac. Journal of the American Veterinary and Medical Association, v. 225, n. 4, p. 503,2004

TAUBER, J. et al. Double-masked, placebo-controlled safety and efficacy trial of diquafosol tetrasodium (INS365) ophthalmic solution for the treatment of dry eye. Cornea, v.23, n.8, p.784-792, 2004.

TERMOTE, S. Parotid duct mucocele and sialolithiasis following parotid duct transposition. Journal of Small Animal Practice, v.44, n.1, p.21-23, 2003.

TREPANIER, L.A. Idiosyncratic toxicity associated with potential sulfonamides in the dog. Journal of Veterinary Pharmacology and Therapeutics, v.27, n.3, p.129-138, 2004.

TREPANIER, L.A. et al. Clinical findings in 40 dogs with hypersensitivity associated with administration of potential sulfonamides. Journal of the American Veterinary and Medical Association, v.17, n.5, p.647-652, 2003.

VAN der WOERDT, A.; ADAMCAK, A. Comparative of absorptive capacities of original and modified Schirmer tear test strips in dogs. Journal of the American Veterinary and Medical Association, v.216, n.10, p.1576-1577, 2000.

WEIGT, A.K. et al. Effects of cyclophotocoagulation with a neodiminium: yttrium-aluminium-garnet laser, on corneal sensitivity, intraocular pressure, aqueous tear production, and corneal nerve morphology in eyes of dogs. American Journal of Veterinary Research, v.63, n.6, p.906-914, 2002. 